\title{
The Effects of Free Radicals on Aging Process
}

\author{
Hatice BAŞ* \\ Department of Biology, University Faculty of Arts and Science, Turkey \\ Submission: March 27, 2018; Published: April 12, 2018 \\ *Corresponding author: Hatice BAŞ, Bozok University Faculty of Arts and Science Department of Biology, Yozgat, Turkey, \\ Email: htc.haticebas@gmail.com
}

\begin{abstract}
Aging is a process that brings many changes in the body and free radicals are increasingly remarked responsible for most of these changes. A theory which is called "free radical theory of aging" assumes that accumulation of reactive oxygen species (ROS) caused aging. Additionally, aging is a multifactorial process and this process can not reduce to any one single situation. This review aims to summarize various studies about the role of free radicals on aging process.
\end{abstract}

Keywords: Free radicals; Aging; Oxidative stress

\section{Introduction}

The aging is a very multifactorial and complex biological process. It can be defined as the morphological, functional and structural modifications realized between birth and death [1]. On top of genetic factors, external parameters, such as smoking, nutrition, environmental conditions, alcohol, can promote to its expected appearance. A detailed relevance in this perspective has been paid to the effects of free radicals, particularly to reactive oxygen species (ROS), which are causing "oxidative stress" [2].

There are so many theories about aging process but not a single theory is acceptable. Actually, it is unreliable that only a single theory can describe all the aging mechanisms. "The free radical theory of aging" gives hope among the all of these theories, today. This theory was first suggested by Harman in 1956 [3], and it blamed for the aging process and death of organisms. "The free radical theory of aging" is based on the free radical reactions and their prominent and ubiquitous presence in organisms. The theory supposes that free radical reactions cause production of the aging changes, diseases and the main aging process [4].

\section{Free Radicals and Oxidative Stress}

A free radical is a chemical species such as an atom, a molecule or an ion which contains an uneven number or unpaired electrons. There are many sources of free radicals in biological systems. There are some ways in that free radicals can be generated, but their most prevalent source is the mitochondria that uses $90 \%$ of the $\mathrm{O}_{2}$ in the human body [5]. Moreover, minor amounts of free radicals are produced by electron transport chain located in endoplasmic reticulum, nuclear and plasma membranes. Free radicals which found in biological systems were supposed to be included in aging and various pathological processes [6].

Reactive oxygen species (ROS) are most common free radicals. The ROS value control is provided not only by ROS generation, also by elimination. The production and elimination of ROS are closely related. Biological systems have complicated and multiplex antioxidant systems which minimize negative effects of ROS or eliminate them [7]. Even so, under certain conditionss there is a balance between these two processes but sometimes this balance can be disturbed. Unquestioning, increase in stable state ROS value, that results from imbalance between production and elimination of ROS, can affect many physiological processes such as aging, carcinogenesis DNAdamage and for initiation of many diseases [2].

\section{Effects of Free Radicals}

ROS can cause various damages to biologic macromolecules, such as nucleic acids, proteins and lipids. Especially, polyunsaturated fatty acids of membranes are the most sensitive macromolecules as oxidation targets for ROS. Membrane fatty acids are so sensitive due to lipid peroxidation (LPO) process, because once LPO is initiated, a harmful chain reaction begins [8]. Nucleic acids such as DNA and RNA are also very sensitive to ROS attack. Oxidation of these nucleic acids causes mutations in both mitochondrial and nuclear genomes [9]. Nearly, all amino acids in a protein or in an enzyme can be oxidized by ROS. And these oxidation can cause modifications which lead to losses of function [10]. 
Many different cellular macromolecules can be attacked by ROS but certainly damage to DNA is most considerable for aging, particularly in postmitotic cells for example neurons. Especially, mitochondrial DNA (mtDNA) is nearby to the position of ROS generation in mitochondria. Mutations such as deletions and point mutations in mtDNA, take part with aging processes in postmitotic organs and tissues like as brain [11] and attain high values in aged individuals, particularly in the control region that is answerable for mtDNA transcription and replication $[12,13]$. The altered mtDNA expands towards superiority while aging in these postmitotic cells.

Additionally to formation of ROS, the other property of long-lived animals interrelates oxidative stress with aging: the level of fatty acid unsaturation of biological cell membranes. Unsaturated fatty acids especially polyunsaturated fatty acids are the most sensitive macromolecules of cells against free radical damages, in connection with the existence of unstable electrons. These electrons attack double bonds of unsaturated fatty acids. Their susceptibility to LPO increases exponentially by the double bonds number of per molecule. For this reason, decreased value of fatty acid unsaturation will reduce oxidative stress in cells. Several previous studies have determined that the maximum longevity is actually negatively correlated with the level of fatty acid unsaturation of cells and tissues of mammalian $[14,15]$.

In conformance with a considerable function for ROS in nervous system especially in brain aging [16], various studies point out ROS level and neurodegenerative diseases of neural cells. It is specified that ROS can cause death of astrocytes [17] and neurons [18] by both necrosis and apoptosis. Also, evidences containing ROS in main degenerative disorders is consistent with their function in brain and neuronal aging. There are lots of studies which are agreement with that oxidative stress plays a role in degeneration of dopaminergic cells in Parkinson's disease [19]. Many obtained results specify that oxidative stress is one of the first observed processes in Alzheimer's disease [20]. Considering the studies done up to this time, we can say that there is a strong relationship between free radical caused oxidative stress and aging.

\section{References}

1. Labat J, Robert L (2014) Longevity and aging. Role of free radicals and xanthine oxidase. Pathol Biol 62: 61-66.

2. Getoff N (2007) Anti-aging and aging factors in life. The role of free radicals. Radiat Phys Chem 76: 1577-1586.
3. Harman D (1956) Aging: a theory based on free radical and radiation chemistry. J Gerontol 11: 298-300.

4. Ashok BT, Ali R (1999) The aging paradox: free radical theory of aging. Exp Gerontol 34: 293-303.

5. Wickens AP (2001) Ageing and the free radical theory. Respir Physiol 128: $379-391$.

6. Lushchak VI (2014) Free radicals, reactive oxygen species, oxidative stress and its classification. Chem Biol Interact 224: 164-175.

7. Lushchak VI (2012) Glutathione homeostasis and functions: potential targets for medical interventions. J Amino Acids ID 736837.

8. Niki E (2009) Lipid peroxidation: physiological levels and dual biological effects. Free Radic Biol Med 47: 469-484.

9. Hekimi S, Lapointe J, Wen Y (2011) Taking a "good" look at free radicals in the aging process. Trends Cell Biol 21(10): 569-576.

10. Ugarte N, Petropoulos I, Friguet B (2010) Oxidized mitochondrial protein degradation and repair in aging and oxidative stress. Antioxid Redox Signal 13: 539-549.

11. Nekhaeva E, Bodyak ND, Kraytsberg Y, McGrath SB, Orsouw NJV, et al. (2002) Clonally expanded mtDNA mutations are abundant in individual cells of human tissues. Proc Natl Acad Sci 99: 5521-5526.

12. Kraytsberg Y, Nekhaeva E, Bodyak NB, Khrapko K (2003) Mutation and intracellular clonal expansion of mitochondrial genomes: two synergistic components of the aging process. Mech. Ageing Dev 124: 49-53.

13. Chomyn A, Attardi G (2003) MtDNA mutations in aging and apoptosis. Biochem Biophys Res Commun 304: 519-529.

14. Pamplona R, Barja G, Portero-Otín M (2002) Membrane fatty acid unsaturation, protection against oxidative stress, and maximum life span. Ann N Y Acad Sci 959: 475-490.

15. Barja G (2004) Free radicals and aging. Trends Neurosci 27(10): 595600.

16. Poon HF, Calabrese V, Scapagnini G, Butterfield DA (2004) Free radicals: key to brain aging and heme oxygenase as a cellular response to oxidative stress. J Gerontol 59: 478-493.

17. Rouach N, Calvo CF, Duquennoy H, Glowinski J, Giaume C (2004) Hydrogen peroxide increases gap junctional communication and induces a astrocyte toxicity: regulation by brain macrophages. Glia 45 : 28-38.

18. Sonee M (2003) The effect of tertiary butilhydroperoxide and nicotinamide on human cortical neurons. Neurotoxicol 24: 443-448.

19. Jenner P (2003) Oxidative stress in Parkinson's disease. Ann Neurol 53: 26-36.

20. Honda K, Casadesus G, Petersen RB, Perry G, Smith MA (2004) Oxidative stress and redox-active iron in Alzheimer's disease. Ann N Y Acad Sci 1012: 179-182. 
This work is licensed under Creative Commons Attribution 4.0 License

DOI: 10.19080/CTBEB.2018.13.555871
Your next submission with Juniper Publishers will reach you the below assets

- Quality Editorial service

- Swift Peer Review

- Reprints availability

- E-prints Service

- Manuscript Podcast for convenient understanding

- Global attainment for your research

- Manuscript accessibility in different formats ( Pdf, E-pub, Full Text, Audio)

- Unceasing customer service

Track the below URL for one-step submission https://juniperpublishers.com/online-submission.php 